Medicine Updates

Faculty of medicine

April 2020,volume 1, issue 1 https://muj.journals.ekb.eg dean@med.psu.edu.eg vice_dean_postgraduate@med.psu.edu.eg

DOI:10.21608/muj.2020.15734.1000

ISSN : 2682-2741

Submitted: $6 / 8 / 2019$

Accepted : 2/3/2020

Pages:1-8

\title{
The Effect of Amisulpride on Hippocampal Neurogenesis in an Experimental Model of Stressed Rats
}

Ahmed. Mustafa. Mohamed. Assistant lecturer in pharmacology department of faculty of medicine of port said university

\section{$\underline{\underline{\text { Abstract }}}$}

Rationale: Amisulpride (Sanofi) is atypical antipsychotic against both positive and negative symptoms of schizophrenia . Efficacy is observed against negative symptoms in a low dose range of ( $50-300 \mathrm{mg} /$ day ) while in positive symptoms is observed in a high dose range ( $800-1200 \mathrm{mg} /$ day ) Boyer et al , ( 1994 ). It is a selective and potent antagonist at dopamine D2 and D3 receptors. Also it appears to have a useful potential for treatment of depression Boyer et al ,(1999).

\section{Objectives}

The current study investigated that amisulpride has antidepressant properties over a range of doses in two procedures namely the Forced Swim Test (FST) Porso et al,(1978) and immune-histopathology of Ki67. Also the effect of high versus low dose of amisulpride on hippocampal neurogenesis in male Wistar Han albino rats. 


\section{Methods}

Sixty male albino wistar rats weighing about 150-200 gm are used in three main groups. Group I ( $n=12$ ) were administered vehicle (saline) for 21 days, group II $(n=12)$ exposed to forced swim test (FST) and vehicle (saline)for 21 days, group $I I I(n=36)$ exposed to (FST) and amisulpride. The latter group was divided into three subgroups : IIIA ( $n=12$ ) received $5 \mathrm{mg} / \mathrm{kg} /$ day for 21 days, IIIB ( $n=12$ ) received $10 \mathrm{mg} / \mathrm{kg} /$ day for 21 days, IIIC ( $n=12$ ) received $20 \mathrm{mg} / \mathrm{kg} /$ day for 21days. The rats were observed for behavioural tests as immobility, climbing and swimming times. Then they were anaesthesized using urethane $1 \mathrm{gm} / \mathrm{kg}$ i.p futterer CD, (2004), then decapitated and the brains were quickly removed. Brain samples were placed in $10 \%$ formalin and were processed to form paraffin blocks. Half of them were used for biochemical analysis of BDNF levels in tissue and the other half were prepared and stained with Hematoxylin and eosin ( H\&E )stain and Immunohistochemical staining by Ki 67 (marker for proliferating cells).

\section{Results}

There is an increase of immobility time in seconds in CSS group compared with Control group with Mean \pm SD $(67.00 \pm 8.623$ and $3.333 \pm 1.670$ respectively) with $\mathrm{P}<0.0001$.While treating with oral amisulpride for 21 days in doses of $10 \mathrm{mg} / \mathrm{kg} /$ day and $20 \mathrm{mg} / \mathrm{kg} /$ day result in statistically significant decrease in immobility time as compared with CSS group with $P$ value of $<0.0001$ and $F$ value of $(4,54)=98.67$. Amisulpride in $5 \mathrm{mg} / \mathrm{kg}$ was statistically insignificant.

Also there is a significant decrease in BDNF level in $(\mathrm{pg} / \mathrm{ml})$ in CSS group compared with Control group with Means \pm SD of $(253.6 \pm 45.06$ and463.5 \pm 35.02 respectively ) with $P$ value of $<0.0001$, while treatment with oral Amisulpride in 5,10 and $20 \mathrm{mg} / \mathrm{kg} /$ day result in significantly statistically increase in BDNF value with Means \pm SD $(420.5 \pm 29.84,358.6 \pm 16.72$ and $400.6 \pm 18.18$ respectively)with $P$ values of $<0.0001$ and $F(4,25)=1.276$.

There is a significant statistical decrease in number of Ki-67 positive cells in SVZ in CSS group compared with control group with means (8.000 and 22.30 respectively ) with $P$ value of 0.0101 . Also treatment with oral Amisulpride 5 , $10 \mathrm{mg} / \mathrm{kg} /$ day result in insignificant increase in $\mathrm{Ki}-67$ immunostained cells in 
$\mathrm{SVZ}$, with the maximum statistically increase with $20 \mathrm{mg} / \mathrm{kg} /$ day, with means $(15.78,13.38$ and 28.00 respectively )compared with CSS (Mean 8.000 ) with $P$ values of $0.5108,0.8187$ and 0.0009 respectively and $F(4,40)=6.628$.

\section{Behavioral results:}

Table 1 showing difference in immobility time in seconds among different groups:

\begin{tabular}{|l|l|}
\hline Groups of Rats ( $\mathrm{n}=12$ Rats / group) & $\begin{array}{l}\text { Immobility time in seconds } \\
\text { (Mean } \pm \text { SD })\end{array}$ \\
\hline Control & $3.333 \pm 1.670$ \\
\hline CSS & $67.00 \pm 8.623$ \\
\hline Amisulpride $(5 \mathrm{mg} / \mathrm{kg} /$ day ) & $113.4 \pm 21.09$ \\
\hline Amisulpride $(10 \mathrm{mg} / \mathrm{kg} /$ day ) & $23.58 \pm 14.71$ \\
\hline Amisulpride $(20 \mathrm{mg} / \mathrm{kg} /$ day ) & $20.09 \pm 22.18$ \\
\hline
\end{tabular}

Results are presented as Mean \pm SD ( $n=12$ animals / group ).

Fig 1 by using Graphpad prism :

\section{Immobility time}

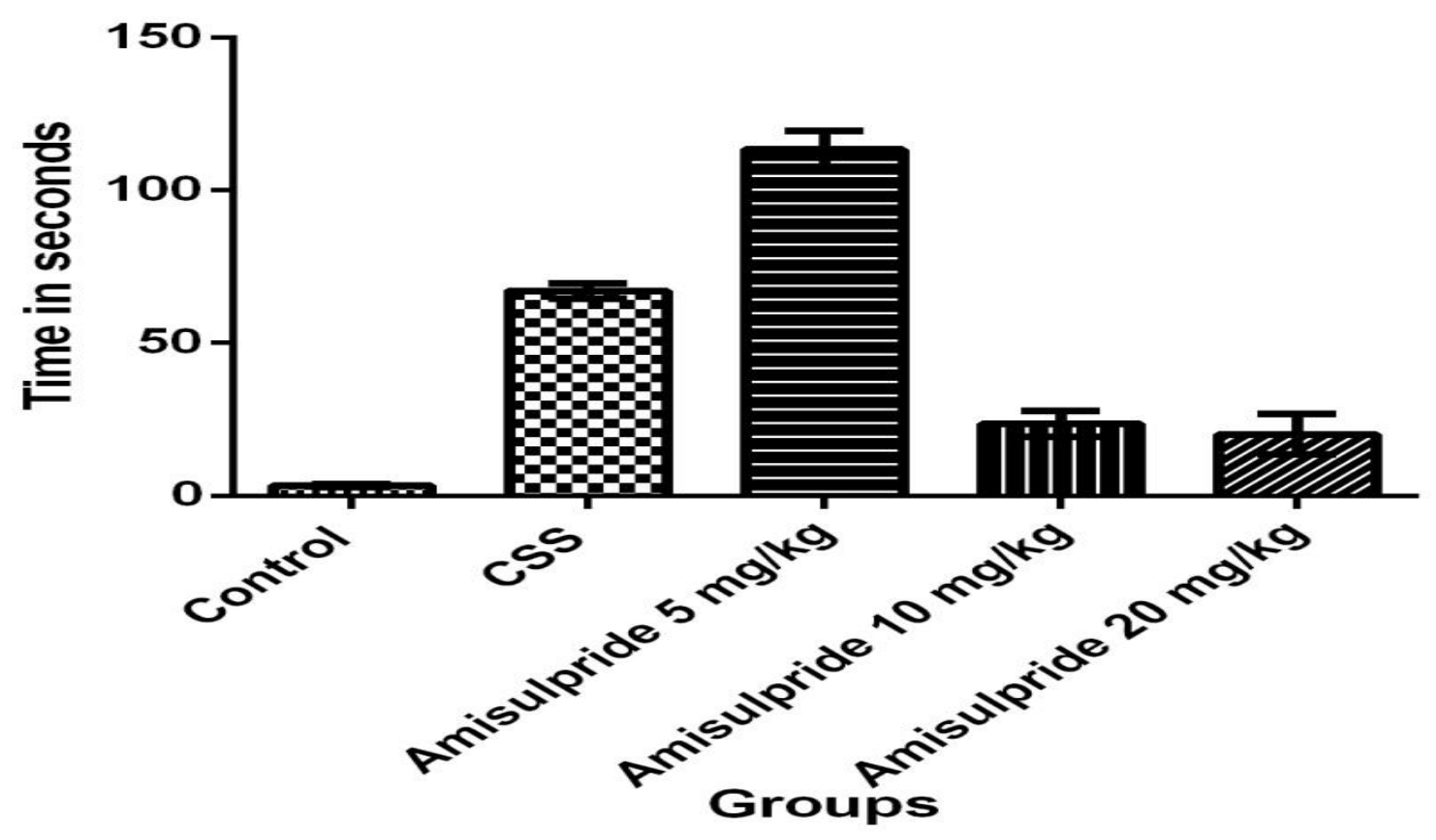




\section{Biochemical results:}

Table 2 showing difference in BDNF levels in (pg/ml)among groups:

\begin{tabular}{|l|l|}
\hline Groups of Rats ( $\mathrm{n}=12$ Rats/group) & BDNF in $(\mathrm{ng} / \mathrm{ml})$ as Mean $\pm S D$ \\
\hline Control & $463.5 \pm 35.02$ \\
\hline CSS & $253.6 \pm 45.06$ \\
\hline Amisulpride $(5 \mathrm{mg} / \mathrm{kg} /$ day) & $420.5 \pm 29.84$ \\
\hline Amisulpride $(10 \mathrm{mg} / \mathrm{kg} /$ day) & $358.6 \pm 16.72$ \\
\hline Amisulpride $(20 \mathrm{mg} / \mathrm{kg} /$ day) & $400.6 \pm 18.18$ \\
\hline
\end{tabular}

Results are presented as Mean \pm SD ( $n=12$ animals/group).

Fig 2: BDNF level

\section{BDNF ELISA}

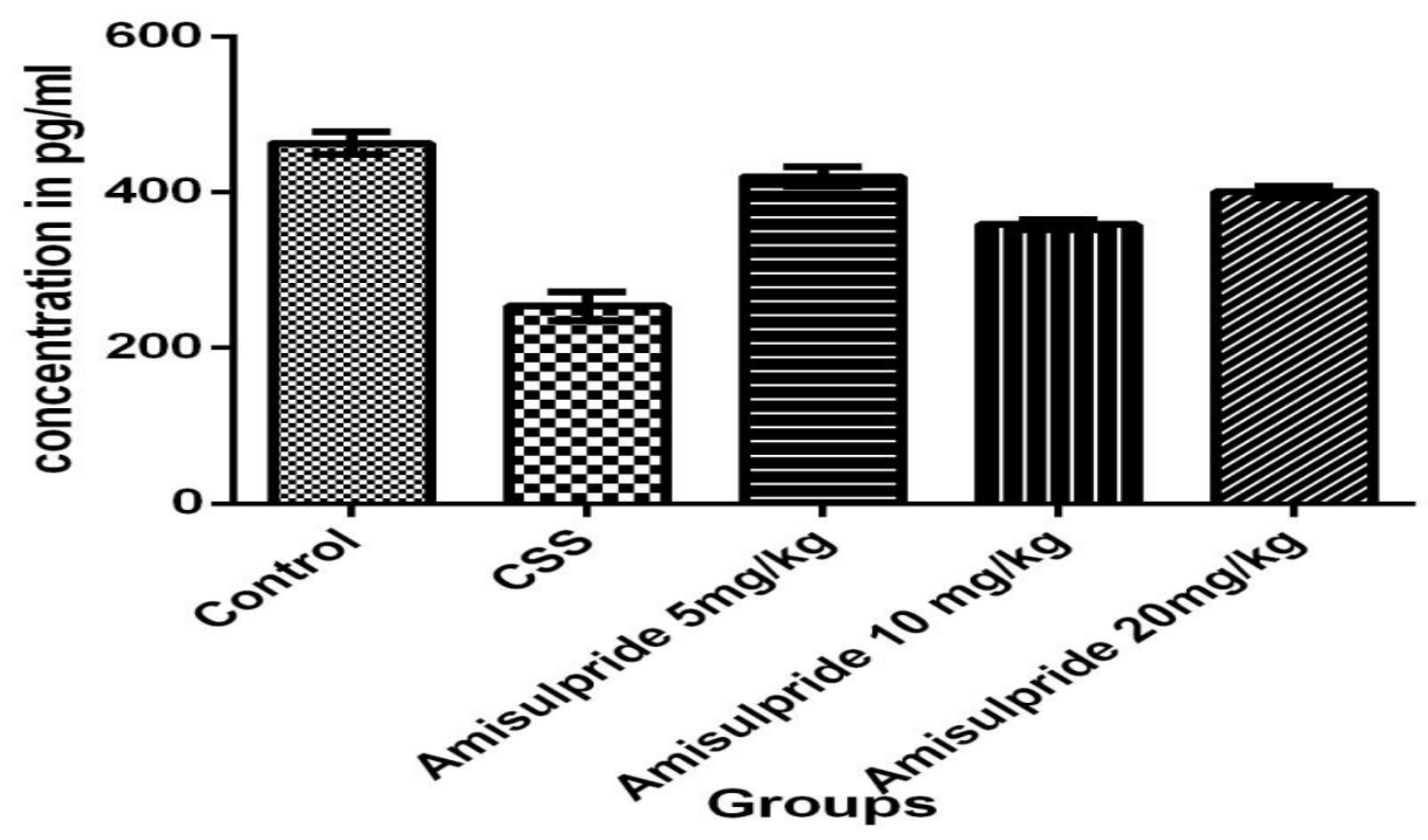




\section{Histological results:}

Table 3 showing number of Ki-67 immunostained cells/HPF in SVZ

\begin{tabular}{|l|l|}
\hline Groups of Rats ( $\mathrm{n}=12$ Rats/group) & $\begin{array}{l}\text { Number of Ki-67 positive cells } \\
\text { in SVZ }(\text { Mean } \pm \text { SD) }\end{array}$ \\
\hline Control & $22.30 \pm 5.229$ \\
\hline CSS & $8.000 \pm 2.966$ \\
\hline Amisulpride $(5 \mathrm{mg} / \mathrm{kg} /$ day) & $15.78 \pm 8.136$ \\
\hline Amisulpride $(10 \mathrm{mg} / \mathrm{kg} /$ day) & $13.38 \pm 5.630$ \\
\hline Amisulpride $(20 \mathrm{mg} / \mathrm{kg} /$ day) & $28.00 \pm 14.75$ \\
\hline
\end{tabular}

Results are presented as Mean $\pm S D, n=12$ animals /group.

Fig 3 Number of Ki-67 immunostained cells/HPF in SVZ.

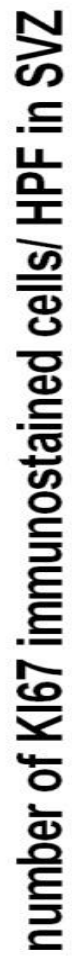

Ki67 positive cells in SVZ

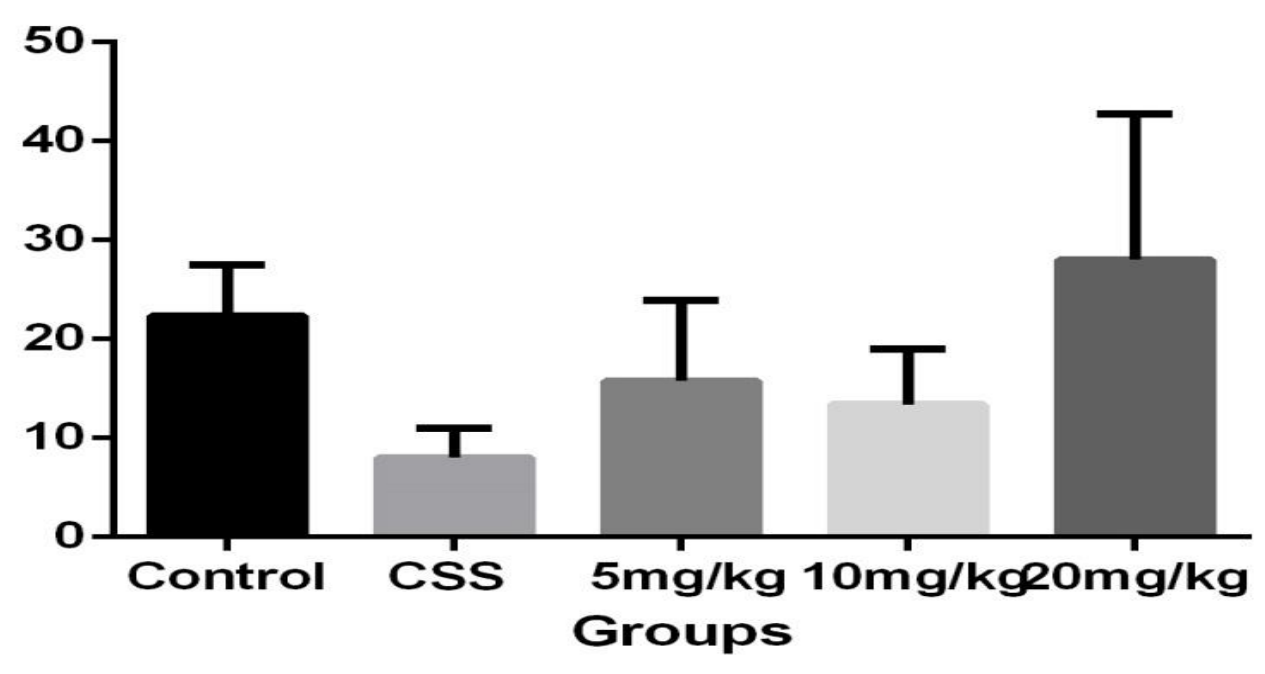




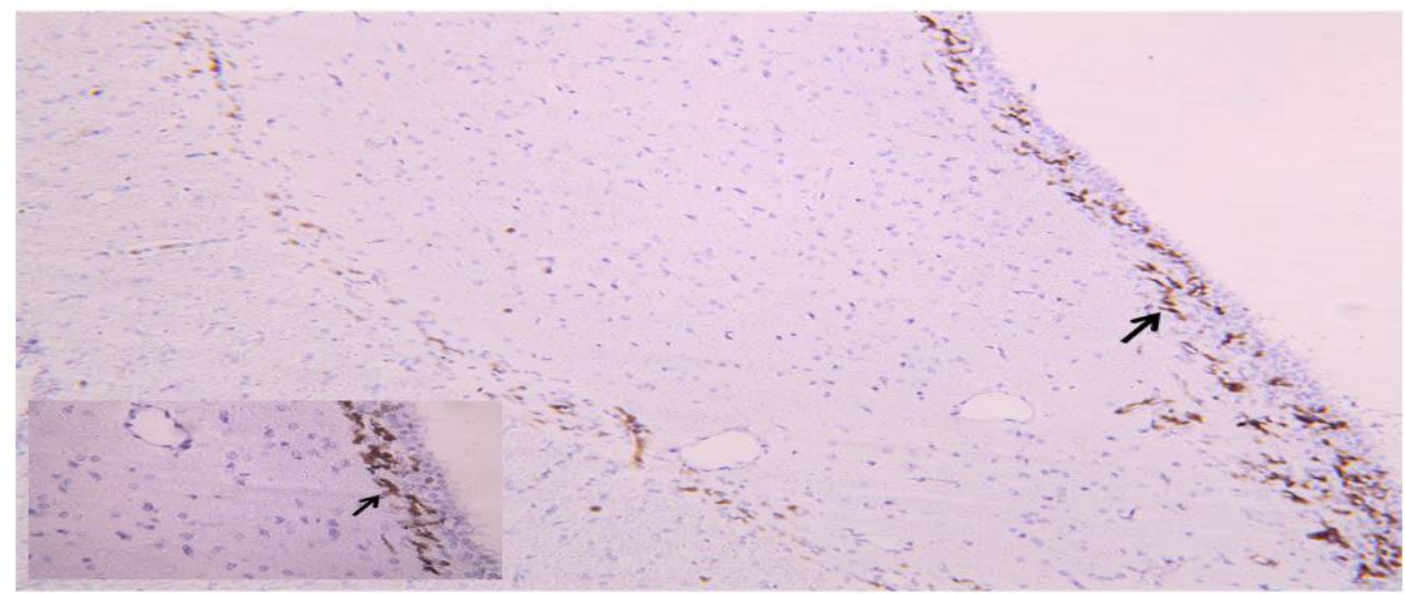

Fig 3 A: Micrograph showing immunohistochemistry of Ki-67 in SVZ ( $\uparrow)$ in the control group (100x, for inset 400x).

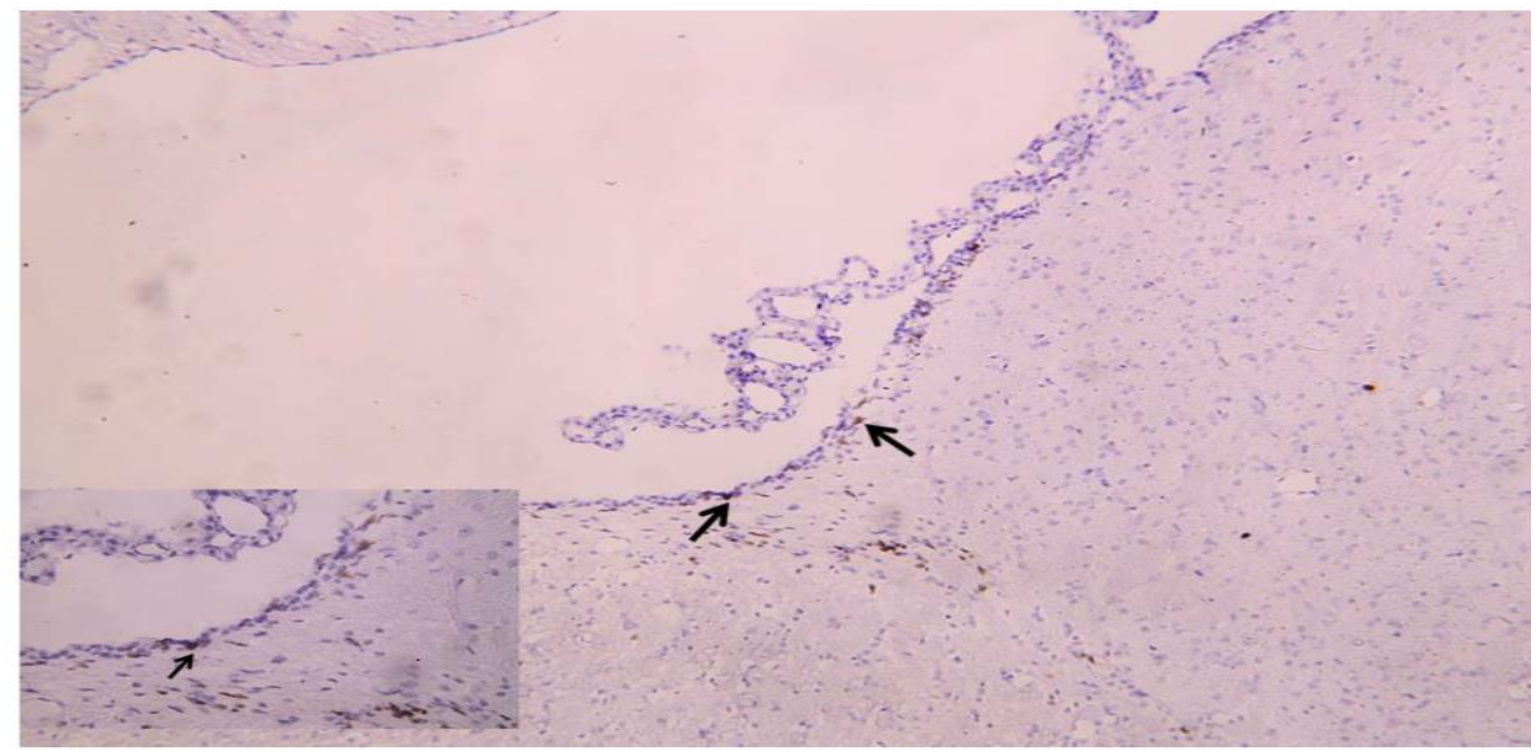

Fig 3 B : Micrograph showing immunohistochemistry of Ki-67 in SVZ ( $\uparrow$ ) in CSS group. A decrease in the number of Ki-67 positive cells is seen (100x, for inset 400x). 


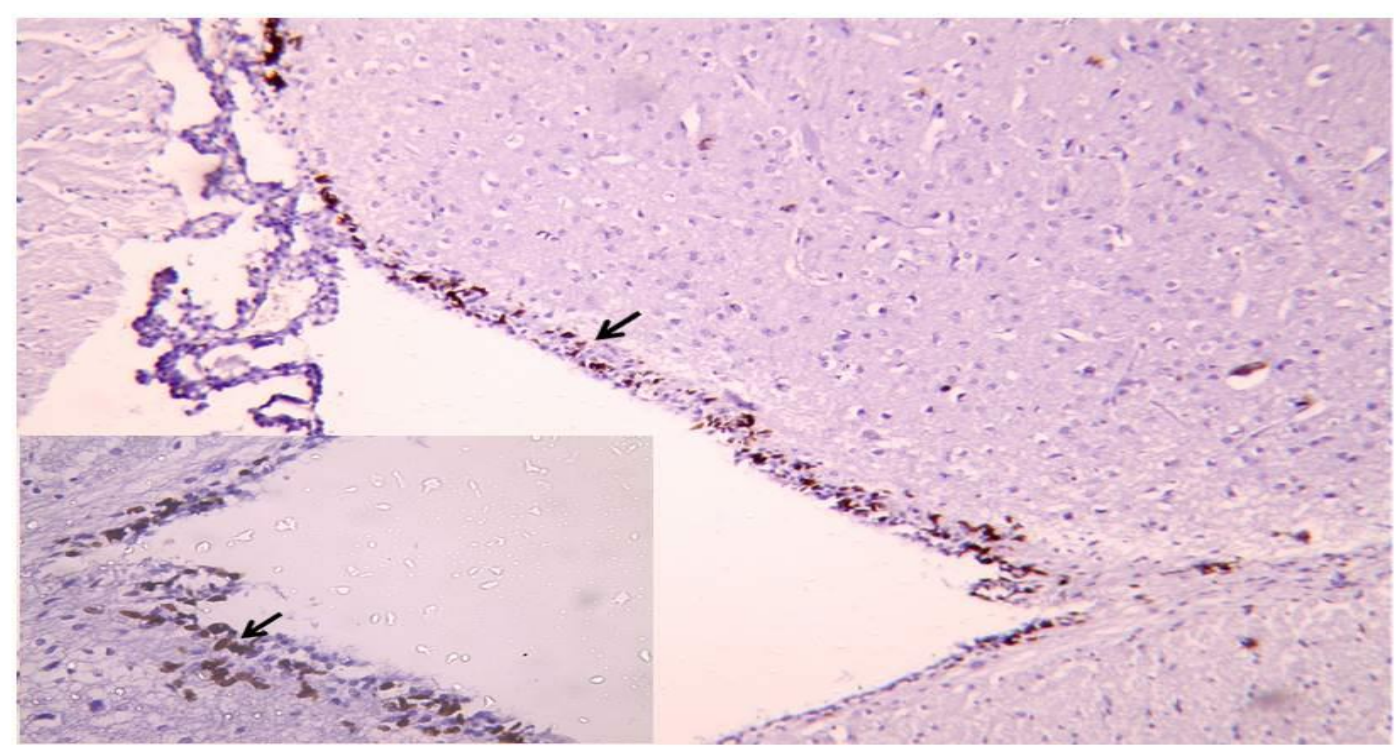

Fig $3 \mathrm{E}$ : Micrograph showing immunohistochemistry of Ki-67 in SVZ ( $\uparrow)$ in amisulpride $20 \mathrm{mg}$ treated group. An apparent increase in $\mathrm{Ki}-67$ positive cells is seen $(100 x$, for inset 400x).

\section{Conclusion:}

Amisulpride showed antidepressant effect over a ranger of doses as in 10 \& $20 \mathrm{mg} / \mathrm{kg} /$ day in addition to its antipsychotic effects. Moreover, the hippocampal neurogenesis may be altered in immunepsychiateric disorders like depression and neurodegenerative disorders.

\section{References:}

1- Benavides J, Boyer, Carter C, Chergui K, Cudennec A, Fage D, Gonon F, Perrault G, Sanger D J, Scatton B, Shoemaker H, Sramek (1994): Pharmacological profile of amisulpride, an atypical neuroleptic which preferentially blocks presynaptic D2/D3 receptors.

Neuropsychopharmacology 10 (Suppl. 1): 242S.

2- Briones TL, Futterer CD, Suh E, Jozsa L, Hattar H, Chai J, Wadowska M (2004). "Behaviorally-induced ultrastructural plasticity in the hippocampal region after cerebral ischemia". Brain Research. 997 (2): 137-46. 
3- Can, A.; et, al (2012). "The Mouse Forced Swim Test". Journal of Visualized Experiments. 59 (3638).

4- Cattaneo A, Cattane N, Begni V, Pariante CM, Riva MA (2016). The human BDNF gene: peripheral gene expression and protein levels as biomarkers for psychiatric disorders. Transl Psychiatry. 6(11):e958.

5- Porsolt, R.D., Bertin, A. \& Jalfre, M (1978). 'Behavioural despair' in rats and mice: strain differences and the effects of imipramine. Eur. J. Pharmacol. 51, 291-294.

6- Porsolt, RD; Le Pichon, M; Jalfre, M (1977). "Depression: a new animal model sensitive to antidepressant treatments.". Nature. 266 (5604): 7302.

7- Raju TR, , Srikumar BN, Veena J (2009) :Exposure to enriched environment restores the survival and differentiation of new born cells in the hippocampus and ameliorates depressive symptoms in chronically stressed rats. Neurosci Lett ;455: 178-182. 